Campbell University School of Law

Scholarly Repository @ Campbell University School of Law

1993

\title{
Medieval 'Ratio' and Modern Formal Studies: A Reconsideration of Coke's Dictum That Law Is the Perfection of Reason
}

J. Stanley McQuade

Campbell University School of Law, mcquades@campbell.edu

Follow this and additional works at: https://scholarship.law.campbell.edu/fac_sw

\section{Recommended Citation}

J. Stanley McQuade, Medieval 'Ratio' and Modern Formal Studies: A Reconsideration of Coke's Dictum That Law Is the Perfection of Reason, 38 Am. J. Juris. 359 (1993).

Available at: https://scholarship.law.campbell.edu/fac_sw/29

This Article is brought to you for free and open access by the Faculty Scholarship at Scholarly Repository @ Campbell University School of Law. It has been accepted for inclusion in Scholarly Works by an authorized administrator of Scholarly Repository @ Campbell University School of Law. 


\section{MEDIEVAL “RATIO" AND MODERN FORMAL STUDIES A RECONSIDERATION OF COKE'S DICTUM THAT LAW IS THE PERFECTION OF REASON}

\section{J. Stanley McQuade}

\section{INTRODUCTION-The ReVIVAL OF INTEREST IN LEgAL LOGIC}

LEGAL LOGIC IS LIKE THE weather; everybody complains but nobody does anything about it. And the complainants have been many. Holmes probably considered himself a radical when he remarked that "the life of the law has not been logic: it has been experience." $\mathrm{His}$ comment would seem almost orthodox now. The general tendency among lawyers is to decry and play down logic as a legal tool and strong critics of one sort or another have been arguing for the better part of a century that it is impossible to apply law logically, that is, in a uniform and fair manner. The subject has also suffered much from its supporters. Books on legal logic continue to be published but most of them are not particularly helpful to lawyers or are misleading in one way or another. Some are not very current, still lingering in the Aristotelian mode, with a little of Mill's inductive logic thrown in for good measure. Others are definitely current with heavy doses of symbolic logic, but these, too, are inappropriate to the needs of the profession. Apart from being generally difficult to read (symbolic logicians incline to radical syntax), they are in a sense no improvement on the more traditional offerings, for much of the material that they use was developed to meet the needs of logicians rather than lawyers: it is concerned with the presentation of conditional sentences and other types of formal argument in symbolic forms. Others attempt to bridge the gap between philosophy and legal practice by reviewing case law in the hope of extracting inductively some special form of legal logic from the writings of judges. ${ }^{2}$ This, too, seems to me to be a misplaced effort since lawyers, including

1. O.W. Holmes, The Common Law (1923), p. 1

2. Julius Stone's discussions of legal logic contain voluminous citations from judicial opinion. These may be illustrative only, but they appear to me to suggest, if they do not altogether say, that legal logic can be derived inductively from judicial opinions. See J. Stone, Precedent and Law (1985). See also J. Stone, Legal System and Legal Reasonings (1964). 
judges, are not creators and programmers of logical systems but users, and it is part of the historical thesis in this paper that they simply take whatever logical tools are available in their cultural environment and apply them as best they can in legal argument.

If the above is an approximately correct summary of the ways in which legal logic is presently viewed, then I would submit that we are not taking advantage of currently available resources. Remarkable things have been happening in the field of formal studies, both in its scientific and its philosophical branches, which are apt for legal use. In the field of formal logic itself much of the old learning, including the distinction between inductive and deductive reasoning, has become obsolete. The basic underlying theory of logic has indeed become very simple and understandable. All logics are seen as games of one sort or another with symbols, rules, and a definition of "winning." And virtually every kind of intellectual endeavor uses logic, defined as above, in some way or other. Scientific enquiries and indeed virtually all disciplines operate with some kind of formal structure, organizing materials in accordance with theoretical models, using number and word games, picture games, or some other kind of formal arrangement. Top level mathematicians work so much with picture logics that video computer games are a major spin-off from their activities. Much of this work, both mathematical and scientific, is computer aided, which should cause us no surprise since the internal workings of the computer are, and are described as, logics.

We need to recover a positive attitude to legal logic, in short to stop tilting at logic and learn to use it. I have no quarrel with those who criticize the abuses of logic by lawyers (weak antinomians); but skepticisr: about logic itself (strong antinomianism) is harmful and ultimately indefensible. If it is based on the proposition that logics will not always apply to life, the argument is weak, for even the physicists have to struggle with indeterminacy. More seriously, like skeptical arguments generally, it is open to the charge of implying what it is trying to destroy, in this case that it is using logic to destroy logic. And this is necessarily so. We cannot argue or even think without word or picture symbols which operate according to formal rules. In short, mentation of every kind, but especially argument, implies logic.

It would be surprising if there were not an important formal aspect to law. Law has always represented an orderly and uniform approach to dispute resolution, and so almost inevitably requires form. Even to settle disputes by the medieval ordeal or by tossing a coin implies some rudimentary sort of formal order. And it has been the hope 
and inspiration of the legal profession, both civilians and common lawyers, that we could provide a formal structure sufficiently complex to resolve all or most of the disputes and conflicts in society in a consistent manner. ${ }^{3}$ Before we surrender to skepticism and throw away two millennia or more of legal tradition, we should at least check and make sure that our critical stance is well founded.

It will be argued here that the main criticisms levelled at the use of logic in law, that it makes law resistant to change and unrelated to life, are misplaced and due to misunderstandings of the nature of formal systems. Forms are not Procrustean beds to stretch and deform life; humane values are an important part of many formal systems; and formalism is not tied to legal conservatism.

The argument is both historical and theoretical. The historical part is in essence a contention that the term ratio in the mouth of the medieval lawyer was a term of art referring to the formal logical structure of a legal system. The theoretical part explores the ways in which we may modify and build on our medieval legal tradition in order to take advantage of modern developments in formal theory generally and computer studies in particular.

The historical part is primary in two senses. First because it was while browsing in the early year books that I noticed a peculiar use of the term ratio which was obviously relevant to modern discussion about legal logic. But it is also important because law, concerned as it must be with continuity and stability, has always developed new forms slowly and deliberately from older models. ${ }^{4}$ It is important therefore for anyone who advocates formal changes in the law, as I do, to show how the newer logics can be fitted into already existing legal theory.

\section{The History of the Term Ratio in Medieval English Law}

\section{A. The Foundation of the Common Law in Reason}

Lord Coke comments in a number of places on the relation between law and reason. In one of the most famous of these passages he remarked:

3. As to our own system, Bracton did not hesitate to fill in the gaps of the common law. Edward I also, with the Statute of Wales and the in consimili casu chapter of the Statute of Westminster 1285, appears to have envisaged an extension of the writ system so as to cover all the legal needs of society. See E. Jenks, "Edward Plantagenet (Edward I), the English Justinian," The Making of the Common Law (1902), pp. 215-20, esp. p. 217; T.F.T. Plucknett, A Concise History of the Common Law (1956), p. 28.

4. See Roy Stone's description of the evolution of property law in his "Compleat Wrangler," 50 Minn. L. Rev. (1966), p. 1001. 
Judges and sages of the law have always expounded general statutes according to the rules of common law, which is built upon the perfection of reason and not according to any private and sudden conceit or opinion. ${ }^{5}$

This statement has often been quoted in humorous, and usually derogatory speeches about the law. It has even occasionally been discussed in law review articles, again usually with adverse comment. ${ }^{6}$ But Coke was by no means unique in speaking this way about the law. Similar statements can be found in the writings of his contemporaries, Bacon and Noy, which shows at least that there was nothing singular or individual in the notion that the common law was based upon reason. Noy, writing in 1577, says: "The common law is grounded on the rules of reason, and therefore we say in argument that reason wills that such a thing be done or that reason wills not that such a thing be done." Elsewhere he remarks that "reason says" and "the law says" amount to much the same thing. In fact one can go back to our earliest records of the common law and find judges and serjeants linking law and reason. The early year books record Serjeant Robert Thorpe complaining in the Court of Common Pleas that it was impossible to know what the law was. unless the Justices would follow precedents. Justice Hillary replied that "The law is the pleasure of the judges." Chief Justice Stonore, however, disagreed saying: "Nay, the law is what is according to reason." Similarly the great Chief Justice William de Bereford is quoted as saying: "The law is based upon reason.",

This kind of statement appears ridiculous and naive today because the word "reason" does not have quite the same meaning for us now that it did for educated persons in the sixteenth and earlier centuries. We need, then, to examine the uses of this term of art, for such it was, in these earlier times in order to understand what it might have meant to Coke and other medieval lawyers.

\section{B. The Use of Philosophical Terms Such as Reason by} Medieval LaWyers

"'Reason," “science," and such words had philosophical implications to educated persons, including lawyers, in the middle

5. 3 Co. Reports fol.13b 468.

6. D. Lloyd, "Reason and Logic in the Common Law," $64 L Q R$ (1983), p.

7. William Noy, Maxims of the English Law (1808) p. 1; W. Noy, Noy's Maxims (1821), p. 1 .

8. W.C.Bolland, The Year Books (1921), p. 18.

9. Ibid., p. 18. 
ages. Coke, Bacon, Noy, and all the other legal authorities mentioned in the previous section may or may not have been acquainted with philosophy as it was taught in the universities. It is quite possible, indeed, that they were not. By the time that the year books were being written, the judges were former serjeants at law, specialists in pleading who had learned their trade in the courtroom. Thenceforth the common law had little direct connection with the universities and so such philosophical notions as its practitioners may have held would have been acquired in the course of their general education and private reading. But though Stonore and Bereford may not have busied themselves much with Greek philosophy, they are bound to have been familiar with its basic concepts. They would indeed have inherited such ideas both from their ordinary education and in their legal studies. They were the heirs of judges who had been heavily indoctrinated with classical learning, the great administrator judges who established the common law in the early thirteenth century. These were men such as Martin Pateshull and William Raleigh, the mentors and heroes of Bracton, ecclesiastics with university training who as enlightened persons of that era would undoubtedly have placed great emphasis on Greek philosophy. Grosseteste in Oxford and Aquinas in Paris were reintroducing Aristotle into the new universities and learned men generally were enthusiastic about their work. The architects of the common law would therefore have been familiar with the major themes and common terms of the thirteenth century revival of classical learning and we can also expect that they would have applied them in their legal work and introduced them into the common law tradition. Furthermore these philosophical ideas were used to develop every kind of education, even its most elementary forms. They thus became an important part of the general intellectual environment which educated persons in succeeding generations, including lawyers, would inevitably absorb, either consciously or by osmosis.

This medieval framework of ideas lasted well into modern times. Scholastic doctrines were always disputed and were indeed being subjected to radical criticism in the age of Coke and his contemporaries. Yet the basic ideas and underlying premises of scholastic philosophy remained alive and influential, especially in the law, until well into the nineteenth century. Since the key notions in classical philosophy are likely, then, to have influenced the common law at its most formative period and to have become part of the English legal tradition, the hypothesis that certain key terms and doctrines in the law have roots in classical philosophy is worth considering. One of the most important of these was ratio. 


\section{The History of the Term Reason in Classical and Medieval Thought}

In the middle ages "reason" was not the rather vague term that it is today. It was a major topic of philosophical discussion and as such it was described and analyzed in great detail. It was distinguished, following Aristotle, into speculative and practical reason and had several meanings. It could be used to indicate the rational faculty, the ability of human kind to reason. It could also describe proper method, the correct and logical way to approach a problem. A third possibility is that it might have been used to describe a product of reason, any organized system of thought on any topic once it has been put into a structured logical form by the faculty of reason. This last (objective) meaning of the term ratio is not exemplified in any of the standard dictionaries of medieval philosophy, but it is acknowledged to be a permissible use of the term and it seems likely that medieval lawyers employed it to describe the logical apparatus of the law.

It is not being argued here that the medieval lawyers consciously framed all their thinking in Aristotelian terms, but this way of thinking is implicit in their utterances. All uses and forms of the word reason by medieval thinkers and their Greek mentors assumed that reasoning, if it is to be worthy of the name, should proceed in a certain manner and follow an approved form which is essentially deductive and indeed almost geometrical in type. Plato, a fervent admirer of mathematics in general and geometry in particular, depicts his teacher and hero Socrates solving problems by first deriving general principles like the axioms of mathematics and then showing how the solution flows deductively from them. This pattern of logic was accepted by the later admirers of the Greeks as the proper approach to virtually any enquiry and as the very essence of scientific method. The terms reason and science are indeed almost synonyms. And just as the term "science" with us can imply both method and doctrine, so the phrase "reason says" is likely to have carried an implicit reference in the middle ages to an ordered body of knowledge expressed in a particular logical form.

\section{Legal Usage of the Term Reason}

The expression "reason says" might then mean something quite different to a medieval lawyer than it would to his modern counterpart. The idea of reason in the sense of a geometrically organized body of knowledge was probably incorporated into legal theory from its 
very beginnings in republican Rome. The wealthy patricians who became the first jurisconsults had been introduced to some form of Platonic thinking in a number of ways, but especially by wandering Stoic philosophers. The influence of Stoic philosophy on the development of legal theory in republican Rome is well known, ${ }^{10}$ but the most important aspect of that influence, the logical heart and core of it, is often missed or passed over very lightly. The Stoa was a somewhat debased form of Platonism, but the essential Platonic doctrines were still discernible. Young men of good family were attracted to the Stoic teachings, and central among these was the emphasis on reason. It is highly probable indeed that the enthusiasm which patricians in the late republic developed for the study of law was fired by the expectation that this new method would transform their civic duty to act as magistrates into a worthy intellectual pursuit. It was customary, then, for young men from the ruling families to spend some time as judges, hearing complaints and settling disputes, before they began their career in public service by entering the army. Their duty to the law, originally viewed as a rather unimportant chore, could be reevaluated in the light of the Stoic notion of reason as an intellectual task worthy of the devotion of a lifetime. Once law is seen as a proper field for the exercise of reason it becomes natural to organize and apply legal materials in a quasi-mathematical manner. Savigny, who was thoroughly acquainted with both classical and modern Civil Law, saw this method as the principal contribution of the Roman jurisconsults to legal science. He remarks of them that, like mathematicians, they viewed the understanding of the basic principles or axioms as the most important part of the subject. Once these were mastered, all the rules that they might need could be derived from them and applied to whatever practical problem they might be considering. He says of them that "they calculated with words" and further that "they saw the principles in the instances and the instances in the principles and moved easily from the one to the other."11 The geometrical associations of these terms are quite clear; the principia (principles) correspond to the axioms and the instantia (cases) to the individual triangles, squares, and other particular shapes which could be derived from the axioms.

10. See Cicero on the Commonwealth (1929), p. 36. E. Bodenheimer, Jurisprudence: The Philosophy and Method of the Law (1967), pp. 13-20.

11. F.C. von Savigny, On the Vocation of our Age for Legislation and Jurisprudence (A. Hayward, trans, 1831), p. 47. 
The vocabulary of the medieval lawyers clearly indicates that they too were familiar with and used such concepts and premises. ${ }^{12}$ The term regula, which we might be tempted to translate as rules, is not plural but singular and is used by medieval writers to refer to a general principle or a set of such principles. ${ }^{13}$ Regula indeed here must be taken in the Platonic sense as a heavenly measure or ruler, something by which lower and more earthly things are judged. Bacon thus calls his maxims a regula and the regula of Boniface VIII is a collection of pithy legal sayings, for the most part general principles, many of which found their way into English Common Law (especially Equity). In English legal writings such very general rules are referred to as maxima (the greatest rules) and principia (principles). These terms indeed are also synonyms for the axiomata of geometry. Coke himself makes this clear saying:

A maxime is a proposition to be of all men confessed and granted without proofe, argument or discourse. Contra negantem principia non est disputandum (there can be no argument about first principles). ${ }^{14}$

This is nothing other than the standard geometrical description of an axiom as a self-evident proposition, one which cannot be doubted without running into a contradiction of one sort or another.

In the daily round of a busy lawyer, awareness of such precisely defined philosophical concepts would no doubt slip into the background of consciousness, and with the passage of time they might become more implicit than explicit ideas. This indeed seems to have happened with the Roman jurisconsults who were more anxious to discuss problems and cases than to refer back constantly to their philosophical underpinnings. But there is evidence that such ideas persisted and that they were considered important at least by thoughtful teachers and practitioners of the law. The clearest example of this is found in Sir John Fortescue's Dialogue in Praise of the Common Law (1537), in which the author, a judge in exile during

12. Coke, commenting on Littleton remarks, "That which our Author here and in other places calleth a Maxime, hereafter he calleth a Principle, and it is all one with a Rule, a common ground, Postulatum or an Axiome, and it were too much curiosity to make nice distinctions betweene them." E. Coke, 1 Institutes (1979), p. 11

13. I am heavily indebted, here as elsewhere, for such understanding of medieval ideas as I possess to Prof. James McEvoy of the Catholic University of Louvain and to his teacher and mine, the late Rev. Father Theodore Crowley, Professor of Scholastic Philosophy in Queen's University, Belfast.

14. A comment on $\S 90$ of Littleton's Tenures. Coke, supra at fol.67a. 
the Wars of the Roses, endeavors to instruct his pupil, the young prince, in the legal duties of a king. Replying to the youth's objection that he would not have time to become sufficiently expert in the law to know what was going on, Fortescue remarks:

as for the principia, which the Commentator calls the efficient causes, these are no other than certain universalia, which the learned in the law, as well as mathematics, call maxims. ${ }^{15}$

Legal education in the Inns of Court also appears to have emphasized the principia and so to have accepted the geometrical model as the proper form in which law should be understood and presented. Noy, Bacon, and Coke all used maxims (regula) as the central organizing principles in their teaching and writing.

The move away from the geometrical model of formal thinking, so far as lawyers are concerned, begins with Bentham and Austin. Bentham was actively hostile to any suggestion that formal logic might be a good thing. Austin's attitude was typically equivocal. On the one hand, he was impressed by the logical studies of his friend and pupil, John Stuart Mill, ${ }^{16}$ which he utilized from time to time in his analysis of law. On the other hand, he was powerfully influenced by radical empiricist theories of knowledge based on the writings of Hobbes and Hume. So although Austin talked much of the importance of understanding principles, they do not feature much in his writings. Central general concepts seem to be replaced by rather specific commands, and if his thinking here is read in the light of Bentham's doctrine of the infima species, ${ }^{17}$ making legal categories as narrow as possible, then he will be seen as advocating an associationist view of legal propositions-that $A$ (a set of facts) is associated with $B$ (a legal consequence), with the $A$ s and $B$ s defined as narrowly and particularly as possible. Whether Austin intended this result or not is a good question, but at any rate he seems to have been read in this light by later interpreters. Such an interpretation would be reinforced no doubt by the increasing ascendancy during the nineteenth century of radical empiricist philosophy in scientific circles. Scientific thinkers, at least the more hard nosed variety, viewed general propositions with suspicion and tried to keep theory as close to the known facts as possible. This trend continued well

15. Sir John Fortescue, Commendation of the Laws of England (F. Grigor, trans. 1917), p. 14.

16. W.L. Morrison, John Austin (1982), pp. 55 ff.

17. Ibid., p. 44. Morrison here discusses Bentham's notion of the infima species and his project of reducing law to particular rules. 
into the twentieth century. It is arguable, of course, that Austin was merely an early example of a tendency which later became more widespread among legal theorists, but it can probably be claimed with some justification that he appreciated it early and facilitated and expedited its assimilation into legal philosophy.

But however or by what means it happened, the trend away from deductive modes of legal logic began to be influential in the midnineteenth century. The vision of law as a quasi-geometrical science became dimmed, though it was never quite eclipsed. Collections of maxims continued to be published into the present century ${ }^{18}$ and traces of the classical Greek thought remain discernible, though faintly at times, in legal language.

\section{E. Coke's View of Legal Ratio and Its Perfection}

We are now in a position to ask what Coke may have meant when he described law as the perfection of reason. He says, speaking of the common law, that:

Reason is the life of the law, nay, the common law itself is nothing else but reason; which is to be understood of an artificial perfection of reason, gotten by long study - and not of every man's natural reason. . . . This legal reason est summa ratio. And therefore if all the reason that is dispersed into many several heads were united into one, yet could he not make such a law as the law of England is; because by many successions of ages, it hath been . . . refined by an infinite number of grave and learned men, and by long experience grown to such a perfection for the government of this realm, as the old rule may be justly verified of it, Neminem opportet esse sapientiorem legibus: no man (out of his own private reason) ought to be wiser than the law which is the perfection of reason. ${ }^{19}$

This comment, which could be matched by many others scattered throughout both his Reports and Institutes, throws considerable light on the way Coke thought about law. It seems clear from these remarks that law, since it is the product of reason and of rational men, is reason incarnate. He says that it is the highest reason. If Coke is not speaking of law as a systematically organized body of

18. The fifth edition of Broom's Maxims was produced in 1885. A collection of more than one thousand maxims was appended to the Latin for Lawyers (1937).

19. Coke, supra, at fol.97b. Elsewhere he remarks of the common law in a similar strain, "It is not the work of any one man but that the wise and learned in many ages had developed and improved it so that it can be described as the product of reason." Coke, supra, at fol.98b. 
knowledge, he is coming as close to such a statement as his language and categories of thought would allow him.

Coke is not merely eulogizing law in general terms, then, when he describes it as perfect reason. He is making a statement as to its logical form. His praise of the law may not even be extravagant. It must in his view be treated carefully and should not be altered lightly since it represents corporate wisdom and many generations of experience..$^{20}$ It is identified with reason in the sense that it is the product of great minds and also because it is a rational system, geometrical in its logical form. Yet though he does not doubt that this system is generally beneficial, even Coke is aware that it has its limitations. He cites with approval the maxim that the law more readily tolerates a private harm than a public evil and Littleton's comment that the law will allow a mischief rather than an inconvenience, ${ }^{21}$ which at least acknowledges that the law can in individual cases work harm and mischief. These maxims must be understood in the light of the formal theory of law outlined above. It means that it is better that one person should be hurt by a rule (a mischief) than that many should suffer harm from uncertainty about the law (inconvenience). Inconveniens, the Latin term used here, means ill-fitting, implying that something is not consistent with the logical structure of the law. ${ }^{22}$ This is in line with another and better known maxim that "hard cases make bad law," except that it is more explicit as to the nature of the harm.

20. The maxim, Omnis innovatio plus novitate perturbat quam utilitate prodest, i.e., innovation by its very newness produces more confusion than it does benefit, was well known. 2 Bulstrode's Reports 388. Cited in Latin for Lawyers, p. 214.

21. Coke, supra, at fol.152b. See A Concise History of the Common Law, p.680. Littleton had remarked that to allow a certain case to succeed would be an "inconvenience." Coke cites two maxims by way of explanation, the above in English (which he elsewhere gives in Latin as Nihil quod est inconveniens est licitum [Coke,supra, at fol.97a] and also Lex citius tolerare vult privatum damnum quam publicum malum, i.e. a private loss is preferred to a public evil) [Coke, supra, at fol.152b]. He comments "it should be holden for an inconvenience that any of the maximes of the law should be broken though a privat man suffer loss . . . (otherwise) ... a publike uncertainty and confusion would follow." Coke is here using the term "maxim" loosely, as he sometimes does, to refer to any legal rule, not general principles only. Also, equating public harm'with an inconvenience (inconsistency) in the law he says, Quod est inconveniens aut contra rationem non permissum est in lege. [Coke, supra, at fol.178a]

22. By inconvenience Coke means something which does not fit into the scheme of things (including the law) rather than in our sense of an annoying but relatively harmless problem. Thus he, and Littleton, both comment that for a woman to say to a man (paying homage on becoming his feudal tenant) "I will be your woman" is inconvenient. [Coke, supra at fol.66a] 
Coke's insistence on the importance of order and consistency in the administration of law is reasonable enough. His viewpoint might be made even more defensible by a few interpretative comments. One could, for instance, import the "state of the art" defense. Such mischief as is worked by the law need not be considered imperfection if it is designed and constructed as well as contemporary conditions (the state of society and the knowledge available) allow. In other words "perfect" could be taken to mean not defective.

One might also interpret and perhaps rephrase Coke's dictum to say that "law is the perfect-1NG of reason." This translation, in the present continuous rather than the past pluperfect tense, would surely be no great concession even for such an admirer of the common law as Coke. The need for change is implied in the maxim (which he quotes) that "when the reason changes [reason as purpose here rather than ratio or logical form] so does the law." ${ }^{23}$

The medieval categorization of law as incarnate reason may not, then, be as ridiculous as it might first appear and we may now proceed to discuss the notion of law as ratio in general terms and in particular in reference to modern theories about logical form.

\section{Redefining Ratio in Modern Formal Terms}

\section{A. Wittgenstein's Views on Mathematics, Logic, and LANGUAGE}

Any restatement of medieval legal reasoning for present purposes inevitably requires some reference to the doctrines of contemporary language/logic studies which emphasize that language should be understood from a logical standpoint as a species of applied calculus. Some of these writings are confusing and even destructive of legal enterprises. Others, especially the later writings of Wittgenstein, are particularly apt and helpful in considering questions about the formal structuring of a legal corpus.

Ludwig Wittgenstein, the midwife if not the father of the view that language was essentially applied calculus, had two opinions as to how words related to "things." In his earlier work, ${ }^{24}$ he had

23. Cessatione ratione legis cessat et lex. Coke, supra, at fol.70.b

24. L. Wittgenstein, Tractatus Logico-Philosophicus (Pears and McGuinness, trans. 1963). See propositions $1-3.144$. He later described his position at that time as saying "a proposition is a logical picture of a fact." Ludwig Wittgenstein and the Vienna Circle (B. McGuinness and J.N.Y. Schulte, trans. 1979), p. 185. See A. Kenny, Wittgenstein (1975) esp. Ch.3 for Wittgenstein's criticisms of his earlier ideas on this subject. 
thought that words or systems of words "stood for" or "represented" things so that if there were no "things" corresponding to a word or words, then that language had no direct meaning (although it might indirectly represent some emotion). Later he developed the more workable formula that the meaning of a language calculus depended on what you were trying to do with it-in short that meaning was related to function. He remarks, for instance, "where lies the difference between chess and the syntax of language? I reply . . . solely in their application." $25 \mathrm{He}$ expresses this link between meaning and function elsewhere, remarking "it is only in use that a rod is a lever." 26 Some language systems point to things, but some are jokes intended to produce a laugh and so on. The long and the short of this view is that functions, ends, goals, or whatever you choose to call them, are an essential part of any applied language system. A "pure" language, if such a thing exists, would be simply a game with no requirements other than internal consistence. In applying any formal system, there are three prerequisites:

(i) The calculus, a consistent system of symbols and rules, must be described.

(ii) The data or things to which it is being applied must be identified.

(iii) The purposes and objectives of the enterprise must all be specified.

This last, the purpose requirement, is most important. The same calculus can operate quite differently when it is applied to different things, or to the same things but for different purposes, even though its symbols and their interrelations are identical in all cases. A good example of this can be found in Boole's algebraic logic. It sounds strange for instance to find Boole saying that $\mathrm{X}$ multiplied by $\mathrm{X}$ equals $\mathrm{X}$ (not $\mathrm{X}^{2}$ ) unless we remember that he is applying the symbols of ordinary algebra for an unusual purpose, to represent Aristotelian formal logic. ${ }^{27}$

This simple view of the relationships between language, formal logical systems, and scientific thinking is now widely accepted and clearly has applications in legal theory.

Wittgenstein did not, so far as I am aware, discuss legal formalism directly, but the applications of his ideas to law are obvious. The

25. Ludwig Wittgenstein and the Vienna Circle, p. 104. See also "the meaning of a word is the way it is used," p. 169.

26. L. Wittgenstein, Philosophiche Bemerkungen (1964), p. 58.

27. P. Nidditch, The Development of Mathematical Logic (1962), p. 42. 
three formal elements which he emphasizes, logical apparatus, applications, and purposes, could all be included in a definition of law, for instance that law is "word calculus applied to disputes to produce justice." 28 Most definitions of law can be transposed into this kind of format and it can be very helpful to view them in this way. Reduced to common form they may be compared with one another and the virtues and deficiencies of each of them (from the formal point of view) made clear.

Aquinas, for instance, could be paraphrased as saying that "law is a dispute-resolving apparatus, geometrical in form, arranged so as to agree with the principles of Natural Law as nearly as circumstances will allow." Or Savigny can be interpreted as saying that law is "sets of word calculus systems arranged in geometrical form, developed and maintained by the legal profession, which are applied in order to regulate social behavior in a manner that will facilitate the customs and mores of the community."

Major differences between different definitions are more easily seen when they are laid out formally in this way. It will be apparent, for instance, that Savigny mainly differs from the medieval lawyers in his view of the purposes of law, since he substitutes the facilitation of custom for maximizing justice as the major end and purpose of applying legal calculus. ${ }^{29}$ It is also obvious that Austin's view (that law is the aggregate of the general commands of the sovereign) ${ }^{30}$ is deficient from the language/calculus point of view if he is understood as saying that moral principles and policy considerations are not part and parcel of the law. Endeavoring to apply a rule or a set of rules without stating the purposes and objectives of the enterprise is to attempt the impossible. Calculus systems do not become usable in the law or anywhere else until their objectives and goals have been supplied.

28. This is intended as a general statement of the purpose of law in the Platonic sense where justice is described as a harmony (metron). [Republic, Bk.IV 443D] The analogy is to the tuning of a harp when each component string is adjusted to the mathematically correct length, i.e., given its proper measure or value. This is a broader, and I think a better, notion of justice than the common legal acceptance where it is equated with fairness, meaning equal treatment of persons. See J. Finnis, Natural Law and Natural Justice (1980), p. 163, where the term "proportionality" is mentioned as one of the three elements of Aristotle's concept of justice. The version adopted here, however, may be even broader than that of Finnis.

29. On the Vocation of our Age for Legislation and Jurisprudence, pp. 21-30, esp. p.26.

30. J. Austin, Lectures on Jurisprudence (1913), p. 71. 
Above all it becomes clear using this simple model that important legal theorists are not agreed as to the form of ratio, the formal structures according to which legal materials should be arranged, and to this topic we will now proceed.

\section{B. The Medieval Model of legal Calculus}

As was mentioned earlier the logic espoused by Coke and his medieval predecessors derives ultimately from Platonic sources. It may be represented roughly as follows:

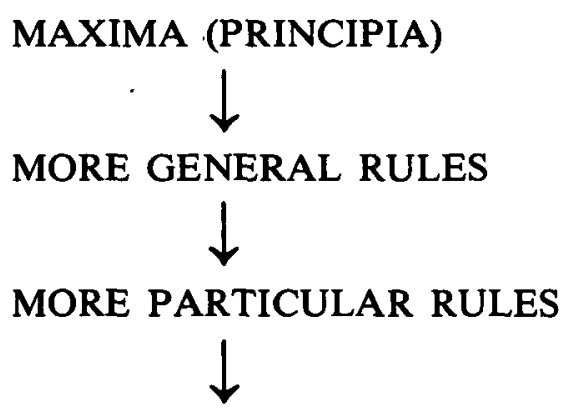

INDIVIDUAL CASES

There is no doubt that the medieval lawyers and their jurisconsult predecessors admired this quasi-geometrical way of thinking and followed it as far as they could. Yet though they all but officially declared themselves Euclidians and used the language of axioms and instances, it is not clear that they were correct in their perception of themselves. Even if we grant, with Savigny, that they calculated with words, it does not follow that the form of their legal calculus was the actual geometrical model described above. ${ }^{31}$ The fact that they moved easily in both directions between the first principles and the cases says nothing about how they reached the one from the other.

It is doubtful indeed if the medieval advocates of deductive logic did use or could have used a strictly geometrical model very much or very often. The work of language/logic philosophers has made it plain that virtually every enterprise which can be called scientific uses structural systems, but they make it equally clear that the form which suits one discipline may not fit in well with another. The Platonic mode of thought, linking particular statements through more and

31. Wittgenstein would probably describe the professed geometrical form of legal logic as surface logic, just as the rules of grammar are the surface logic of language which does not necessarily describe how language calculus systems function. 
more general propositions and ultimately deriving them from first principles, was used by Aristotle as the model for his formal logic. Yet this was only really suitable in one type of logic, the logic of classes ("all men are mortal", etc.). Formal logic had to break with this model at a certain point in its development in order to deal with other types of argument such as the logic of spatial and temporal relations. The geometrical model also proved to be a strait jacket for a number of sciences. That it did not seriously impede the development of legal systems is probably due to the fact that the founding fathers of our jurisprudence were not primarily philosophers or logicians and did not attempt to tailor the law very rigidly to the geometrical model. Any attempts to analyze legal logic in a geometrical fashion have a strained look about them and it is difficult to imagine a practicing lawyer actually functioning in this manner. Pound's well known attempt in this direction is a good example. ${ }^{32}$ His contention, developed in opposition to the radical epistemologies of the Realists, that the structure of law is not and should not be considered merely as a list of rules, is well taken and sound. His representation of that form is more doubtful. He generally favors a complex logic using both particular. rules and more general forms. Pursuant to this he lists and attempts to distinguish all sorts of categories such as rules, principles, policies, and doctrines. He is able to give examples of most of these formal entities but nowhere shows how they relate to one another nor how they would function as a logical system. The principal reason for this failure appears to be that Pound's representation of complex form is still stated in classical Platonic/ Aristotelian quasi-geometrical terms. Legal science must develop its own forms, which should be apt for legal problem solving. It should not even be assumed as a starting premise that there is a single logical form appropriate for all departments of the law and for every type of legal problem. This is not so in any other discipline and is no more likely to be true in legal studies.

\section{A Simple Model of Modern legal Calculus-The DeCisional TREE}

This is hardly the place, were I able to do so, to develop a program for legal formalism, but one or two examples may be helpful to indicate the kind of beginnings that $I$ think are possible and feasible in law and indeed implicit in much of our teaching and practice.

32. R. Pound, "Hierarchy of Sources and Forms in Different Systems of Law," 7 Tul. L. Rev. (1933), p. 475. 
Suppose that instead of concentrating on propositions, we focus our attention upon words, treating them as the symbols in a calculus game, the equivalent of the pawns, knights, and other pieces in chess. It is true that legal rules are commonly expressed as sentences, but this is merely a surface arrangement. The deeper and truly logical structure relates to elements, like the elements in the Roman formularies or the writs of common law. These are technical terms and they are not linked together by the rules of grammar but in word games of various sorts. Roy Stone ${ }^{33}$ cites Russell and Whitehead as saying that all mathematics boils down to two key terms "and" representing conjunction and "or" representing dissociation. Both of these games are played out in legal theory. The "and" game allows the coincidence of a number of subsidiary words, which we describe as elements, to activate a more important term or key-word (like "crowning" a piece which has reached the opponent's base line on the checker board). Thus when the familiar tetrad of duty, breach of duty, causation and damage have been shown, the status word $\mathrm{d}^{34}$ negligence appears. Each of the elements of course can themselves be key words which become active when certain other elements are produced. Thus causation, one of the elements of negligence, only appears when two other elements, sine qua non and proximate cause have been shown. When we proceed to consider damage in more detail we play the "or" game. The term "or" here is taken in its weaker logical sense where the alternatives are not mutually exclusive. Any one kind of damage will be sufficient to activate this term and all of them may do so.

Setting this out formally we can say then that in the "and" game the elements are arranged in the form:

$$
A+B+C=X \text { (the activated term) }
$$

whereas in the "or" game they are represented by

$$
\mathrm{A} \text { or } \mathrm{B} \text { or } \mathrm{C}=\mathrm{X}
$$

Virtually any functioning part of the law can be analyzed in this manner. The basic elements of offer and acceptance together constitute a bargain and this together with consideration (or something else deemed to show legal intent) constitutes a legally enforceable contract. Procedural law and remedies can be represented in the same way.

33. "The Compleat Wrangler," p. 1011.

34. Pierce describes status words as terms which signify that something or someone is to be treated differently. Examples would be "married", "of age" or "dead." "True" would also be a status word applied to propositions. 
In organizing law formally by these simple logical devices we are only doing what the learned and wise in the law have always done; but we are also looking at something strangely modern, something in fact very like the algorithm or decisional tree of computer logic. Lawyers have not been wont to diagram their logic but the methodology is essentially the same.

\section{Legal Calculus-The Place of "Principles," "Policies," "Rules," AND "FACTS"}

Principles are usually defined as general rules and stated as general propositions. It is implied in this that the less general propositions and ultimately the instantia or cases can be derived more geometrico from the most general principles. But this kind of logical linkage is very difficult to show and the propositional form conceals the way in which these more general notions operate. If they too are seen as terms, the matter becomes more clear. A principle may be defined thus as a word game which operates in more than one type of case. A more general principle is one that operates in many varieties of case. Thus the principle that "fraud vitiates consent" can be treated as an elements game in the form:

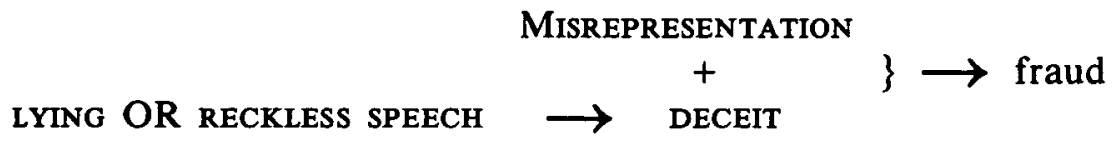

This little piece of word calculus may operate in the law of contracts, in the tort of misrepresentation, in the intentional torts and in several varieties of crime with somewhat different consequences in each. Viewed in this way, there is no great mystery about the nature and workings of a principle and there is no reason why we should think that principles are linked to one another deductively or in any other way. They are simply logical tools of more or less general application, any or all of which may be applicable to a particular case.

"Policies" on the other hand, viewed from the language/logic perspective, should be seen as the values or purposes which the application of legal logic is intended to realize. Thus the proposition "equity hates deceit," which might in an older view be seen as the general proposition from which "fraud vitiates consent" was derived, might be more conveniently classified as an item among the aims or objectives served by the application of a legal calculus to a particular kind of dispute. The term fraud in this case operates as a policy word, whereas, as was shown in the previous paragraph, it can also 
operate as a technical term of general application or, in other words, as a principle.

The remaining terms which require comment, "rule" and "fact", turn out to be interrelated since outlining the ways in which legal calculus is applied to fact situations is a very good way of explaining what we mean by rules.

The term rule or regula, as was mentioned earlier, originally referred to a general principle or measuring rod by which actual laws or legal decisions at law were judged or evaluated. During the nineteenth century, however, rules were increasingly viewed as sentences or statements expressing commands, and generally as rather particular and concrete commands where a specific kind of behavior is either forbidden or enjoined. ${ }^{35}$ Rules at this point are largely defined in terms of the salient facts, and it has proved a difficult matter to show how these specially relevant facts can be picked out from all the others and assembled into a rule.

Matching a fact situation with the appropriate part of the law is a crucial and often difficult matter both in law school and in legal practice. Not only lawyers and courts but juries also must undertake this task. They may be asked to determine not merely whether the facts are so (Roy Stone's alpha fact questions ${ }^{36}$ ), but also whether those facts constitute negligence or some other legal entity (aleph fact questions). This is a complex matter, and so it is hardly surprising that legal writers differ a good deal as to what a rule is and how it relates to facts.

Much of the difficulty here disappears when the problem is seen, in language/logic terms, as bringing fact situations under key words rather than applying propositions to facts. Relating law to fact situations is indeed formally identical with a technique used to teach the Aristotelian logic of classes. This is hardly surprising since saying that a certain set of facts can appropriately be included under a particular legal term is rather like considering whether a particular bug should be considered a member of the class of insects or not. The logic of classes has traditionally been explained to students by drawing pairs of circles which may be within one another, totally separate from one another or intersecting. Where circle $A$ is entirely inside circle B, this will represent the proposition "all A is B." Separate circles represent "no A is B" and intersecting circles represent "some A is B." Legal writers explain the application of legal terms

35. John Austin, p. 44.

36. "The Complete Wrangler," p. 1009. 
and rules to fact situations in much the same way: providing examples that clearly come under them, others which clearly do not, and a few on the borderline.

\section{ALL A IS B NO A IS B SOME A IS B}

A rule in this context can be clearly and conveniently defined as a case or a group of cases where the facts are so clearly within all the circles representing the key terms that the application of the relevant calculus system is obvious-so obvious indeed that the calculus can for practical purposes be ignored. Once such a set of facts is stated, the legal consequences follow. One does not run over the elements of negligence when a doctor arrives in surgery drunk and manages to kill the patient or a demented and unattended patient falls out of bed and fractures his hip. These clear cases are probably the type of thing which Austin had in mind when he spoke of law as commands, or that Oliphant envisaged when he defined law in terms of sets of facts which will predict the legal outcome. They do not feature much in law school discussion or in appellate opinion where more complicated situations are more likely to be under consideration. They are likewise not much considered by those who claim that legal calculus is systematically vague and that judicial discretion allows the court to decide things more or less as they would wish. Nevertheless they are very important and are probably operative a great deal more frequently than one would think from simply perusing law reports and law review articles. Since the application of the law in these circumstances is clearly established, they may discourage people from engaging in actionable behavior. In the event of a complaint, the matter may well be settled before trial; if tried (say on the issue of damages), it is unlikely to be appealed and if it is not discussed at the appellate level it will hardly get into law review articles or text books.

This notion of the relationship between calculus and fact situations will be taken up again later when the doctrine of precedent is discussed.

\section{E. The Place of Values in Legal Calculus}

A major benefit of the word calculus model of legal logic is that it makes it easy to see the place and function of values and policies in legal argument. If a language/calculus model of legal logic is adopted, these function as the ends and purposes for which the apparatus is applied. This arrangement can be represented diagrammatically as: 
LOGICAL APPARATUS

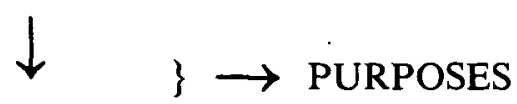

\section{APPLICATION}

The concept of purposes or objectives is central to Wittgenstein's theory about the meaning of language. Even if the same term is applied to the same things but for different purposes, this makes for a difference in meaning. One can thus be dead for one purpose (to allow physicians to discontinue life support) but alive for others (a wrongful death action or a murder charge). ${ }^{37} \mathrm{~A}$ statement of aims and objectives is therefore a necessity in describing applied calculus systems, including the use of mathematics in the physical sciences. It is particularly important, however, in legal theory, since the whole point of law and legal thought is to realize aims and goals. Legal science is not descriptive in the sense that physical and social sciences are, determining how things actually are. It is practical reasoncalculus aimed at realizing things which ought to be (in other words, values and the policies which favor those values). An applied calculus of legal terms is not fully described so far as its logical form is concerned until the values and policies which it seeks to realize are properly listed.

\section{Benefits of the Word Calculus Approach to Legal THEORY}

\section{A. The Limitations of Logic in the Study of Law}

Before considering the benefits of viewing law as applied word calculus systems it is well to mention the limitations which all interpretative definitions share, including this one. First and foremost it must be remembered that definitional categorizations are rarely true or false. They are more likely to be categorized as adequate or inadequate, useful or useless, and we must also remember that what is useful for one purpose may be less so for another. Defining law as ratio is thus not intended to be the sole or sufficient way of looking at it. No definition can cover all important aspects of the

37. See Commonwealth v. Goldston, 373 Mass. 247 1778, 366 N.E. 744 (1978). 
thing defined. Certain items are heavily emphasized and others are only lightly touched on or even left out altogether.

It is not therefore being argued here that legal scholarship and legal education consist solely in identifying, defining, relating, and applying key terms. ${ }^{38}$ Legal calculus and its applications can and should be studied from many points of view, economic, moral, political, and so on. To limit the study of law to formal analysis alone would isolate it from other disciplines and make it unfit for a place in a university curriculum. But conversely, searching critiques of law from various perspectives presuppose, or should presuppose, a knowledge of its basic structure. The study of law in this country is professional education. Airy-fairy legal education which omits these fundamentals is like teaching the sociology of food in catering school to people who neither know how to cook nor what a recipe is.

There are a number of clear advantages in treating law as applied calculus and these will be considered in the following sections.

\section{B. Legal logic as a Research, Teaching, and Communication DeVICE}

Fuzziness and error become evident when a section of law is laid out systematically as a decisional tree. It is doubtful indeed whether anyone can claim to really understand a segment of law properly if they are unable to represent their knowledge formally by laying out the key terms and their interrelationships. Reviewing such diagrams can reveal the limitations of one's understanding and may suggest ways to improve it. They are also an excellent means of communication, both in teaching and in legal argument.

The "two circles" device, mentioned earlier, is also helpful in considering the application of the law to any problem. This is indeed how standard legal textbooks have always shown the "meaning" as opposed to the definition of legal terms, using positive, negative, and borderline instances. One of the major ways in which purposes and values come into operation in legal argument is in deciding these borderline cases (the other is when the law is being changed). In deciding, for instance, whether a vendor has cured a defect in an item sold so that the buyer cannot exercise his right of rejection (i.e. whether buyer or seller behavior falls inside or outside the circle), two rules have been given by courts, the objective (reasonable buyer)

38. His would be the "pure" theory of law as defined by Hans Kelsen. A similar pure definition of legal formalism is given by Michael Corrado, "The Place of Formalism in Legal Theory," 70 NCL REV. (1992), pp. 1545-61. 
and the subjective (actual buyer) rules. Which of these is the better rule depends essentially on the objectives of that particular part of the Uniform Commercial Code. If the purpose is to prevent fraudulent persons returning goods just to get out of the deal, then the subjective test is appropriate. If, on the other hand, the purpose is to prevent buyers who are too picky from returning goods, then the applicable standard is the objective one.

There is nothing particularly new in these ways of managing law. Black letter teachers have always insisted that the nuts and bolts of the law should be learned by definitions, listing of elements, and the use of typical examples. They have also tended to justify decisions (moving marginal cases into or out of the circle) by showing how these would conflict with or be consonant with the objectives of the law at that point. Identifying what we are doing as applying word calculus is only putting established practice in its proper theoretical setting and also providing ourselves with useful formal techniques to avoid confusion and to aid communication.

\section{Using Language/Logic Techniques to Resolve Conceptual Problems-The Doctrine of Stare Decisis}

Language philosophy has found one of its major uses in disentangling knotty conceptual problems. ${ }^{39}$ One of these problem areas in legal theory is the doctrine of stare decisis and we seem to have created most of our difficulties here by getting away from the classical definition of law as ratio. Whether the credit (or blame) for this change should be laid at the door of John Austin or not, the question is most conveniently discussed in terms of the doctrines attributed to Austin and his admirers. The ratio decidendi of a precedent case, which alone is supposed to be authoritative, has been identified in Austinian terms as the proposition or propositions (construed as narrowly as possible) which are necessary to decide the case. $^{40}$ The clumsiness of this statement is probably good evidence

39. See G. Ryle, "Systematically Misleading Expressions," Language and Logic vol.I (A.G.N. Flew, ed. 1973), p. 11.

40. Austin's own formula in Lectures on Jurisprudence is somewhat vague: "The general reasons or principles of a judicial decision (-abstracted from any peculiarities of the case) are commonly styled by writers on jurisprudence, the ratio decidendi." [p. 318] The various ways in which the ratio decidendi, propositionally conceived, may be interpreted can be seen in the exchange between J.L. Montrose and A.W.B. Simpson in $20 \mathrm{Mod}$. L. Rev. (1946). The various writers do not agree on what actually is binding in the case (material facts, judicial opinion, implied judicial opinion). The usual view is that, whatever it is, it is not necessarily the reason or reasons given by the judge. Even more fascinating possibilities emerge when several judges concur on the same case but give different reasons. See J.L. Montrose, "The ratio decidendi and the House of Lords," 20 Mod. L. Rev. (1946), p. 124. 
of the conceptual confusions lurking within it. What is the nature of such a proposition and how is it to be found? The simplest way out is to take the reasons given by the court to be the true ratio. Courts, however, do not always give an opinion and later courts may even conclude that the rule mentioned in the opinion was not the one really required to decide the case. ${ }^{41}$ The ratio decidendi of a case in Austinian terms may be difficult to find, and this uncertainty can be used to distinguish precedent cases at will and so drive a coach and four through the doctrine of stare decisis.

Statements of the doctrine of precedent by judges and writers prior to Austin put it a little differently. Lord Mansfield, for instance, says that precedents are evidences and examples of what the law is, ${ }^{42}$ a formula which seems to derive from the medieval notion of law as ratio. It is ratio, the formal legal apparatus, that judges use to decide cases. To understand what a case stands for in these terms is to identify the piece of legal apparatus that was used to decide it. Judges in practice usually construct their opinions along these lines except that they do not always lay out the whole calculus in each opinion, but only refer to such parts as happen to be immediately relevant. The entire calculus of negligence will hardly be brought out and aired in each case where it is applied, and in some it may seem to be ignored. Many, if not most cases, are so easily decided that no lawyer will bother to do more than indicate the simple rule which covers it. Even in cases where there is some difficulty in coming to a decision, only one term in the system may be in question (though the rest of the apparatus, or indeed several other calculus systems, may be impliedly operative). In novel or borderline cases, however, the whole apparatus, values and all, may need to be explicitly considered.

\section{The Place of Logic in Reform of the LaW}

A structured logical approach to legal theory has often been associated with a very conservative attitude to law reform, but this is not necessarily the case. Formal structure preserves the continuity and consistency of law, but there is no reason why the logical system or its manner of application should not be changed. Savigny, more

41. In one notorious case, Goss v. Goss, 2 All E.R. 617 (1947) a puisne judge distinguished the views of a superior court as obiter. On review by that court his remarks were declared obiter and a learned commentator later opined that this declaration was itself obiter. See 64 Law Q. Rev. (1948), p. 15.

42. See C.K. Allen, Law in the Making (1963), p. 217. 
than any other legal theorist, has stressed the importance of formal structure for law, but he also pointed out most emphatically the duty of the legal profession as curators of the law on behalf of society to continuously maintain and update legal calculus. Proper form is indeed particularly important when law is being altered since it prevents uncertainty as to the effects of the changes. If new measures are not integrated into the old system, confusion follows which can take generations of litigation to cure. Legislative reforms and judicial opinions often fail at this point. Even when new rules are well thought out and clearly expressed, it is not always evident how they relate to provisions already in existence..$^{43}$ Treatises or articles criticizing the law can likewise be formally deficient. An article on the law of nuisance, for example, may cast a great deal of light on the ways in which it became the mess that it is, pointing out how it became mixed up with trespass to land and the rule in Rylands v. Fletcher and so on. All this work is valuable but incomplete until the logical muddle is replaced by a clear formal proposal. Computer novices quickly learn that new hardware and software should be integrated into and matched with the systems already in place. The same considerations apply when we are introducing new notions and applications into the law.

\section{E. Logic and the Computerization of the LAW}

Computers are a feature of almost every compartment of modern life, including the law. They have been used to organize routine office tasks, for legal research, and to reduce the incidence of mistakes and omissions by providing checklists and other warnings. We hear almost every day of new uses for computers, new software specifically designed for particular legal tasks, etc. It is becoming increasingly important, then, to organize legal information in such a way that it will be apt for computer storage, retrieval, and processing, and this will involve consideration of form and system. Formal considerations are particularly likely to be of importance in working with the new "expert" systems which are coming into use in medicine and elsewhere. A vast quantity of information may be organized in these systems in the form of decisional trees designed to answer

43. Section 402A of the Restatement of Torts is a notable example. Much of the confusion and attendant litigation that followed the widespread introduction of this provision in the sixties could have been avoided if its formal relations with older remedies, such as implied warranty, negligence etc. had been made clear. 
specific questions. This kind of software is already being put to work in clinical medicine and in many cases is sufficiently sophisticated to outperform experienced clinicians. Medical texts are being written with attention to formal structure for use in such programs, and medical journals, especially those intended for clinicians, are featuring decisional trees to aid diagnosis and treatment. Some beginnings have been made in expert systems for lawyers, but computer algorithms are difficult to devise unless the source materials are presented in a formally structured manner. Legal materials presented as word-calculus are tailor made for this task. Lawyers may object, as their colleagues in medicine have done and continue to do, that professional judgment is being replaced by electronic decision-making but this is not really the case. Expert systems have not replaced clinical judgment in medicine, but rather assisted it; reminding, suggesting, and generally acting as a combined map and guide book. Decision making has become too complicated for us and we need help. But whether we like it or not, the computer age is upon us and we should be willing to meet its challenge and take advantage of it. Otherwise we may be ranked with those who said "Orville, that thing will never fly."

\section{Future Developments in Legal Logic}

\section{A. The Need to Improve Legal Logic-Provision of Lists of RULES}

Even where it is not warped and confused, the common law can be inadequate because of the poverty of its conceptual apparatus. Oliphant's criticisms about overgeneralization in the law are surely well taken. ${ }^{45}$ Broad general terms like "reasonable" are grossly overworked. Particular kinds of (reasonable) behavior should be isolated, described, and fitted into the appropriate part of the legal apparatus. It is here that rules, in the narrow sense of particular fact patterns with a predictable legal result, become important. The complexities of life do not allow law to be universally reduced to this form, but such legally significant fact patterns do occur and recur with some frequency. In every jurisdiction at a given time,

44. Bishop Wright, the father of Orville and Wilbur, is credited with the remark, during a discussion on the future of scientific discovery with a colleague who was a college president, that if God had intended man to fly he would have given him wings.

45. H. Oliphant, "A Return to Stare Decisis," 14 A.B.A. J. (1928), p. 71. Reprinted unabridged in G. Christie, Jurisprudence (1973), pp. 665-82, esp. 671ff. 
particular common sets of facts will bring a case under a general rule in a hurry. If a sponge or an instrument is left inside the abdomen by a surgeon, there is no need to discuss the general duty of the doctor to exercise due care; the case falls within a precisely determined category under the general term negligence, and there is nothing more to be said, at least on that point. Particular rules, in this sense, exist; and many of them, like the example given above, are well known. But others are hidden away in case law ${ }^{46}$ and they should be sought out and listed under the appropriate term in the legal calculus (in the case in question, under professional medical negligence). Such lists should of course be kept up to date; for changed times and circumstances can render the rules obsolete.

\section{B. Improving Legal Logic-Listing Goals and Objectives}

The fact that the language-calculus approach to law makes objectives an essential part of legal logic has already been mentioned. Legal reasoning is not remote from life and human values merely because it is orderly. But the value and policy statements which direct and control the application of any piece of legal calculus are more likely to be helpful if they are concrete and particular rather than vague and general. And herein lies a problem. The basic values that are held in common by the members of any society (unless it is a very homogeneous one) tend to be somewhat vague and general. This is indeed the real difficulty with Natural Law theory. ${ }^{47}$ Basic values, such as the general principles of natural law or the goals of economic efficiency or fairness, are accepted more or less universally and are indeed axiomatic and undeniable in one way or another. But they are so general that they can hardly be expressed in meaningful sentences. In this form they are not very helpful in moral discourse. Different people can apply them in diametrically opposite directions. The duty to value and preserve life does not prevent sincere people from holding different views on abortion or capital punishment. Likewise accepting the value of truth and honoring the duty to seek the truth, although a basic essential premise of factual discourse,

46. In North Carolina, for instance, a case where a patient had fallen out of his hospital bed and fractured his hip was hastily settled when it was found that in a precedent case the court had ruled that it was the duty of the medical providers to ascertain that he was confused and take appropriate precautions.

47. The supposed problem, according to most critics of natural law, is that it ends moral enquiry, fixing morality in set and undeniable rules. So Finnis remarks that H.L.A. Hart and other eminent scholars seem to be surprisingly unacquainted with classical natural law theory. Natural Law and Natural Justice, p.26ff. 
will not settle many scientific controversies. The general value of truth must be translated into more particular criteria (such as test/ retest reliability value or standards relating to sampling). Value and policy statements cannot produce predictable conclusions if they are too general, and indeed their usefulness might be said to be in direct proportion to their particularity.

If legal calculus is to work well, it is important that purposes and objectives be listed and laid out in as concrete a form as possible. We will not decide difficult cases well if we content ourselves with saying that health or education or economic prosperity are our goals. We need to go further and determine rather that the cost of hospital care must be reduced or that standard test scores must be improved or that the national debt must be lowered. We conduct most of our practical reasonings and disputes with such derived policy principles. If we are asked to justify particular policies, we may then attempt to derive them from more basic principles, but not otherwise.

The logical paths by which we move from general to particular values are complex and generally involve ontological beliefs and beliefs of a factual nature. Thus a policy about the disciplining of children in the home might involve biblical notions about the relationships between parents and children and also psychological views concerning the effects on children of punishment or the lack of it. Fortunately, lawyers do not really need to become deeply involved in this kind of philosophical enquiry since legal values mainly rest on common agreement and compromise. But the task of the legal theorist is not much easier on that account. There is, in fact, a conflict endemic to the very business of selecting and expressing values and policies since community agreement is likely to improve as the value statements become more general, but usefulness depends on them being as particular as possible. Providing a list of aims and objectives for any part of the law is therefore likely to be less than ideal. It is difficult to tread the fine middle line without slipping over into overparticularity at the cost of common consent or vice versa. Nevertheless a list of detailed objectives is part of the logical apparatus of the law and it is therefore the business of lawyers to provide it. In a sense it is like the duty to list rules. Particular values, like detailed rules, do not always exist but should be noted and used where possible.

Another difficulty about values is that when several of them are in conflict, as is commonly the case, they are supposed to be weighed against one another, and this is rather a subjective process. It might be theoretically possible to assign numbers to the relevant values in 
a difficult case to represent their importance, but it is not even necessary to do this. The device of dividing multiple factors into major and minor groups will be discussed in the next section and might prove helpful in balancing the claims of competing values.

\section{The Future Development of Legal Formalism}

The formal methods presented up to this point have not been radically different from those traditionally employed by lawyers in the past. It should not be thought, however, that there is no room for improvement. We should in fact be constantly looking for ways to develop our formal capabilities. One way of doing this is to keep an eye on methods being used in other disciplines to see if any of them might work in legal theory. Formal studies are flourishing everywhere, and we should be reviewing what mathematicians, economists, and computer scientists are doing to see if any of it might have legal applications. We should keep an especially careful eye on the applied sciences and information sciences, for there we may find formal materials already adapted and apt for use in the law. Clinical medicine, for instance, has communication and decisional problems similar to those that we experience in law. Doctors arrive at diagnoses and treatment plans, just as judges reach decisions, with the aid of formal criteria which are not always adequate to insure that different clinicians examining the same patient will agree in their conclusions. The area left to individual discretion in judgment calls may be too wide. In order to deal with this problem and ensure greater uniformity of diagnostic opinion or treatment decisions, the basic medical calculus which lists the signs and symptoms typical of each disease category (or the indications for a procedure) has been rendered more precise in its application by dividing findings into major and minor groups. The classical description of the typical pain found in acute appendicitis might be a major finding, while fever or an elevated white cell count, which can be found in other diseases also, would be minor. The diagnosis of acute appendicitis or any other disease will be properly made then when the appropriate number of major and minor findings are present. The entire functioning of the Diagnostic and Statistical Manual of Psychiatric Disorders (DSMIII-R) depends on this kind of logical device. As a result, psychiatrists, long considered the least objective and most inconsistent of diagnosticians, have at least reached the position where they are calling the same sets of findings by the same name. Numerous legal situations are apt for improvement along these lines. Legal writers sometimes provide a list of factors which are supposed to aid us in 
deciding whether the design of a product is reasonably safe or the establishment of a factory is reasonable in a neighborhood. Dividing such lists into major and minor items would be relatively easy. Attempting to determine the number of each of them that would make the decision one way or the other might be more difficult, but it would hardly be impossible. Fine tuning such a system would at least be an interesting program for legal researchers.

\section{Summary and Conclusions}

(1) It has been argued here that the term ratio as used by Coke and other medieval lawyers represents a peculiar legal use of that term, signifying a body of knowledge organized in a formal, logical manner. (2) Representing law in accordance with these ancient ideas requires only minor adjustments to be in line with contemporary notions about language and "game" theories of mathematics.

(3) Legal calculus has been portrayed here using the simplest of logical devices such as key words, elements, central and marginal instances, and so forth, notions that have been familiar to lawyers for centuries. In a computer age, we may find ourselves trying out more sophisticated approaches and perhaps borrowing concepts and techniques from other disciplines such as mathematics, economics, clinical medicine, or from anywhere that we can find something that looks as if it might be helpful.

If this thesis holds true, a number of consequences follow relating to legal investigation and writing, professional education in law, testing of legal competence, and so on. Most importantly it should be noted that the study of law is not merely training for the hurly burly of legal practice, but can and should be a scientific enterprise. Scientific enquiry has two main aspects, imagination and formal structure, both of which are necessary. Without creative thinking, investigation becomes mechanical tinkering, a matter of hit and miss. Without logical ordering, enquiry flounders around and there can be no reliable communication between one researcher and another. These considerations apply to legal studies. Bringing lofty objectives and stubborn facts together in workable rules is not a matter for dull and uninventive minds. Likewise since the study of law is a communal or collegial matter, form and method are essential to ensure good communication and generally maintain orderly progress. The development of a legal corpus along these lines has always been difficult and is not becoming any easier, but it is as feasible in law as it is elsewhere. If neurosurgeons can devise coma scales to ensure reliable observation of head injured patients and to communicate 
with one another about treatments and outcomes, a most difficult and complex matter, lawyers should surely be able to develop adequate formal tools for use in the study and practice of law.

I have referred at several points in this paper to Christian von Savigny whose emphasis on the importance of logical form more than a hundred fifty years ago sounds strangely modern. ${ }^{48}$ It might be appropriate then to conclude by reminding ourselves of two of his most favored contentions. First, that responsibility for the condition of the law will always be mainly in the hands of the legal profession rather than the elected legislature. And second, that a significant part of our task is continually mending and amending legal calculus systems to improve their logical clarity, to facilitate their application to cases, to keep them in line with social change and above all to maximize justice.

In short, the legal profession, like a medieval collegium, should be "perfecting" the "ratio" of the law. If we can succeed in this to any extent the world may again consider us a learned profession rather than mere technicians or, worse, parasites battening on disaster and strife. Even if they cannot go so far they might at least rank us with the inventors of better mousetraps and "beat a pathway to our door." 49

48. One might wonder how Savigny in the early nineteenth century could be so prescient as to future developments in logical theory. The answer is probably that he was not but rather that he was backward looking with his philosophical roots in the middle ages. This medieval cast in his thinking saved him from the excesses of nineteenth century radical epistemology and made him more amenable to modern mathematical theory than his more "with it" contemporaries such as Austin.

49. In this connection it is interesting to find both politicians and economists stressing the need for lawyers in former communist states. Mr. Gorbachev in a broadcast speech on May 31990 stated: "In general, I must say that, since we are now going over to a market economy-we very much need lawyers. In political reform too-we also feel the shortage of competent lawyers." One economic consultant to the Russian Republic recently commented that what Russia needed was not economists but lawyers. 